\title{
PENGEMBANGAN MEDIA PEMBELAJARAN INTERAKTIF TERINTEGRASI SOFT SKILLS DALAM MENINGKATKAN KEMAMPUAN PEMECAHAN MASALAH
}

\author{
Andri Sattriawan ${ }^{1}$, Sugeng Sutiarso ${ }^{2}$, Undang Rosidin ${ }^{3}$ \\ 1, 2, ${ }^{3}$ Prodi Magister Pendidikan Matematika, FKIP, Universitas Lampung, Jl. Prof. Dr. Ir. Sumantri Brojonegoro \\ No.1 Kota Bandar Lampung, Indonesia \\ andrisattriawan1989@gmail.com
}

\begin{abstract}
The purpose of this research is to produce interactive learning media integrated with soft skills to improve students' problem-solving abilities that are valid and practical. This research is a development research that uses the ADDIE development model (Analysis, Design, Development, Implementation, and Evaluation). Research subjects at the implementation stage were grade V students of SDIT Muhammadiyah Gunung Terang Bandar Lampung for the 2019-2020 academic year. Research data obtained from observations, interviews, questionnaires on teacher and student responses to learning media. The results showed that the developed interactive learning media was very valid with a score of $81 \%$ of the material expert validation and the media expert validation of $84 \%$. This learning media is also stated to be practical as the results of the practitioner test get a score of $86 \%$ and student trials of $88 \%$.
\end{abstract}

Keywords: Interactive learning media integrated soft skills, student problem solving abilities

\begin{abstract}
Abstrak
Tujuan penelitian ini adalah menghasilkan media pembelajaran interaktif yang terintegrasi soft skills untuk meningkatkan kemampuan pemecahan masalah siswa yang valid dan praktis. Penelitian ini merupakan penelitian pegembangan yang menggunakan model pengembangan ADDIE (Analysis, Design, Development, Implementation, dan Evaluation. Subjek penelitian pada tahapan implementasi adalah siswa kelas V SDIT Muhammadiyah Gunung Terang Bandar Lampung Tahun Pelajaran 2019-2020. Data penelitian dipeoleh dari observasi, wawancara, angket respon guru dan siswa terhadap media pembelajaran. Hasil penelitian menunjukkan bahwa media pembelajaran interaktif yang dikembangkan sangat valid dengan skor dari validasi ahli materi sebesar $81 \%$ dan validasi ahli media sebesar $84 \%$. Media pembelajaran ini juga dinyatakan praktis sebagaimana hasil uji praktisi mendapatkan skor sebesar $86 \%$ dan uji coba siswa sebesar $88 \%$.
\end{abstract}

Kata kunci: Media pembelajaran interaktif terintegrasi soft skills, kemampuan pemecahan masalah siswa

\section{PENDAHULUAN}

Pesatnya perkembangan teknologi komputer saat ini telah dirasakan dalam berbagai sektor kehidupan khususnya sektor pendidikan, misalnya pemanfaatan komputer tidak hanya sebagai alat yang dipergunakan untuk urusan keadministrasian tetapi juga sangat mungkin dijadikan alternatif dalam pemilihan media pembelajaran. Kemajuan teknologi di dunia pendidikan memberi pengaruh pada media pembelajaran yang digunakan terutama media pembelajaran dengan bantuan komputer dan software.

Kemajuan teknologi saat ini menjadi satu tantangan sekaligus peluang oleh para pendidik dalam meningkatkan kualitas proses pembelajaran di dalam kelas. Guru sebagai pendidik professional dituntut untuk dapat menguasai teknologi ini untuk dimanfaatkan dalam proses pembelajaran di kelas. Proses pembelajaran berbasis teknologi ini digunakan untuk meningkatkan kualitas pendidikan sehingga proses komunikasi dan informasi antara guru dengan siswa bisa menjadi lebih baik.

(Rohendi, 2012) menyatakan bahwa beberapa manfaat teknologi dalam pendidikan sebagai berikut: 
The electronic technology can be used to assist students in comprehending the visual images of mathematical ideas, it also facilitates students in organizing and analyzing data, and helps students to calculate in a quick and accurate way. One technology that can be used is computer stated that the computer can be used as a tool to complement advantage mathematical thinking ia variety of ways In the past and even now, mathematical learning environment in Indonesia is often perceived as annoying, boring, and less stimulating, so the students are forced to learn in an unpleasant and less passionate way. These conditions should be changed into a passionate and meaningfull atmosphere for both teachers and student.

Pendapat Rohendi tersebut menyatakan bahwa teknologi komputer sangat membantu siswa dalam proses pembelajaran. Salah satunya dalam pembelajaran geometri misalnya objek-objek matematika berupa gambar abstrak. Pembelajaran matematika di Indonesia pada umumnya sulit dipahami dan membosankan sehingga siswa kurang berminat untuk belajar. Oleh karena itu siswa merasa terpaksa untuk belajar. Kondisi tersebut bisa diubah melalui pembelajaran yang berarti dan menumbuhkan minat siswa dalam belajar. Adanya interaksi siswa dan guru yang efektif diharapkan siswa mampu mengetahui proses dan prestasi belajarnya oleh karena itu, guru harus mampu membantu dan memberikan arahan dalam proses pembelajaran yang sesuai dengan kebutuhan siswa.

Dalam bidang pendidikan, perkembangan teknologi informasi dan komunikasi telah mengubah cara orang belajar dan memperoleh informasi. Perkembangan ini menjadi suatu tantangan besar bagi pendidik untuk terus memainkan peran penting dalam mencerdaskan anak bangsa di era globalisasi. Tetapi ada satu komponen yang tidak dapat digantikan oleh perkembangan teknologi yang ada pada diri manusia yaitu, emosi, semangat, empati, ambisi dan lainnya. Komponen - komponen yang tidak dapat digantikan oleh perkembangan teknologi ada secara alamiah dan lahiriah dalam diri manusia, kinerja sistem beserta komponen sistem yang mendukung kehidupan manusia tidak semata mata didasari oleh keberadaan alat yang ada tetapi karena adanya dorongan dari dalam diri manusia dalam mengaktualisasikan kemampuannya, dorongan dalam diri manusia tersebutlah yang dimaksud dengan soft skills.

Hendriana (Hendriana, H., Rohaeti, E.E., \& Sumarmo, 2017) menyatakan bahwa soft skills adalah keterampilan seseorang ketika berhubungan dengan orang lain (interpersonal skills) dan keterampilan dalam mengatur dirinya sendiri (intrapersonal skills) yang mampu mengembangkan unjuk kerja secara. (Alex, 2014) mengungkapkan bahwa "soft skills play a significant role in one's success in life particularly in one's profesional". Soft skills memainkan peran penting dalam kesuksesan seseorang dalam kehidupan, terutama dalam diri seseorang. (Chamorro-Premuzic et al., 2010)menyatakan kemampuan soft skills yang dimiliki seseorang dapat mengaitkan kemampuan individual dengan lingkukan sekitarnya. Soft skills merupakan keterampilan yang dapat dikembangkan, dicontohkan, dan ditularkan kepada orang lain. Beberapa cara untuk mengembangkan soft skills seseorang, yaitu dengan menggunakan berbagai pendekatan pembelajaran seperti pembelajaran contextual, problem based learning, learning cycle, inquiry, pembelajaran berorientasi 
critical learning and problem solving. (Hidayati, W.S., 2015) menyampaikan bahwa soft skills yang diberikan kepada siswa/mahasiswa oleh guru dapat diintegrasikan dengan materi pembelajaran.

(NCTM, 2000) menyatakan bahwa problem solving must be the focus of the curriculum. Lebih lanjut NCTM menyatakan bahwa apabila siswa mampu menyelesaikan permasalahan dengan baik akan memberikan keuntungan yang bagus pula. Kemampuan pemecahan masalah memberikan manfaat yang besar kepada siswa dalam melihat relevansi antara matematika dengan mata pelajaran yang lain, serta dalam kehidupan nyata. Sebagaimana (Căprioară, 2015) menyatakan bahwa dalam matematika, problem solving adalah konsep yang paling efektif untuk kontekstualitas dan rekontekstualitas konsep, untuk operasional dan transfer dasar pengetahuan matematika, dan untuk memastikan pembelajaran yang berkelanjutan dan bermakna. Kemampuan pemecahan masalah matematis dapat membantu dalam memecahkan persoalan baik dalam pelajaran lain maupun dalam kehidupan sehari-hari.

Berdasarkan hasil wawancara guru dan siswa SDIT Muhammadiyah Gunung Terang, bahwa matematika adalah pelajaran yang paling kurang diminati oleh siswa. Penyebab yang membuat siswa kurang meminati pelajaran matematika diantaranya mata pelajaran matematika ditakuti karena dirasa sulit oleh siswa. Kurang minatnya dalam pembelajaran matematika ini juga dikarenakan pembelajaran yang dilakukan oleh guru masih menggunakan metode konvensional dan belum menggunakan media pembelajaran interaktif. Dampak dari kurang diminatinya mata pelajaran matematika ini yaitu masih rendahnya nilai rata-rata ujian sekolah kelas VI sebagaimana ditunjukkan dalam Tabel 1.

Tabel 1.

Nilai Ujian Sekolah Kelas VI SDIT Muhammadiyah

\begin{tabular}{|c|l|c|c|c|}
\hline \multirow{2}{*}{$\begin{array}{c}\text { Tahun } \\
\text { Pelajaran }\end{array}$} & \multirow{2}{*}{ Kategori } & \multicolumn{3}{|c|}{ Nilai Mata Pelajaran } \\
\cline { 3 - 5 } & & $\begin{array}{c}\text { Bahasa } \\
\text { Indonesia }\end{array}$ & Matematika & IPA \\
\hline \multirow{3}{*}{$2016-2017$} & Nilai Tertinggi & 90 & 95 & 87.5 \\
\cline { 2 - 5 } & Nilai Terendah & 48 & 30 & 37.5 \\
\cline { 2 - 5 } & Rata-Rata & 76.9 & 56.3 & 68.3 \\
\hline \multirow{3}{*}{$2017-2018$} & Nilai Tertinggi & 93 & 77.7 & 93 \\
\cline { 2 - 5 } & Nilai Terendah & 52.8 & 22 & 55 \\
\cline { 2 - 5 } & Rata-Rata & 74.8 & 47.7 & 73.5 \\
\hline \multirow{3}{*}{$2018-2019$} & Nilai Tertinggi & 94,8 & 89,4 & 94 \\
\cline { 2 - 5 } & Nilai Terendah & 56,7 & 50,3 & 59,7 \\
\cline { 2 - 5 } & Rata-Rata & 78,2 & 67,4 & 80,9 \\
\hline
\end{tabular}

Media pembelajaran interaktif merupakan salah satu teknologi informasi yang memiliki potensi besar untuk meningkatkan kualitas pembelajaran, khususnya dalam pembelajaran matematika. (Nursit, 2016) menyatakan bahwa penggunaan media pembelajaran merupakan salah satu upaya untuk menciptakan pembelajaran yang lebih bermakna dan berkualitas. Untuk meningkatkan kualitas 
pembelajaran dibutuhkan upaya alternatif sehingga dapat meningkatkan hasil yang dicapai dalam pembelajaran tersebut. Banyak sekali software pendukung yang dapat dimanfaatkan dalam pembelajaran matematika untuk meningkatkan kualitas pembelajaran. Salah satu program diantaranya adalah Microsoft Powerpoint (MP). Sebagaimana yang dijelaskan oleh (Suprapti, 2016), microsoft powerpoint adalah software atau perangkat lunak untuk membuat animasi yang menarik dalam waktu yang cepat. Beberapa hal yang menjadikan perangkat lunak ini menarik untuk digunakan adalah berbagai pengolahan teks, warna, dan gambar, serta animasi-animasi yang bisa diolah sendiri sesuai kreatifitas. (Suminta, 2016) menyatakan bahwa dengan powerpoint ini siswa akan lebih tertarik dan perhatiannya terfokus, sehingga akan berimbas pada hasil nelajar yang efektif.

Sebagaimana telah dijelaskan sebelumnya bahwa kemampuan pemecahan masalah memiliki manfaat yang sangat besar bagi siswa dan soft skills sebagai keterampilan yang harus dimiliki siswa dalam kehidupan sehari-hari, maka akan dikembangkan media pembelajaran interaktif terintegrasi soft skills untuk meningkatkan kemampuan pemecahan masalah siswa.

\section{METODE}

Jenis penelitian yang digunakan adalah jenis penelitian dan pengembangan atau Research and Develophment yaitu suatu proses atau langkah-langkah untuk mengembangkan suatu produk baru atau menyempurnakan produk yang ada, yang dapat dipertanggung jawabkan. Subjek penelitian pada tahapan implementasi adalah siswa kelas V SDIT Muhammadiyah Gunung Terang Bandar Lampung Tahun Pelajaran 2019-2020. Data penelitian dipeoleh dari observasi, wawancara, angket respon guru dan siswa terhadap media pembelajaran. Desain dari penelitian ini mengacu pada desain pengembangan model ADDIE yang meliputi 5 tahap, sebagaimana tampak pada diagram alur pada Gambar 1. (Rusdi, 2018).

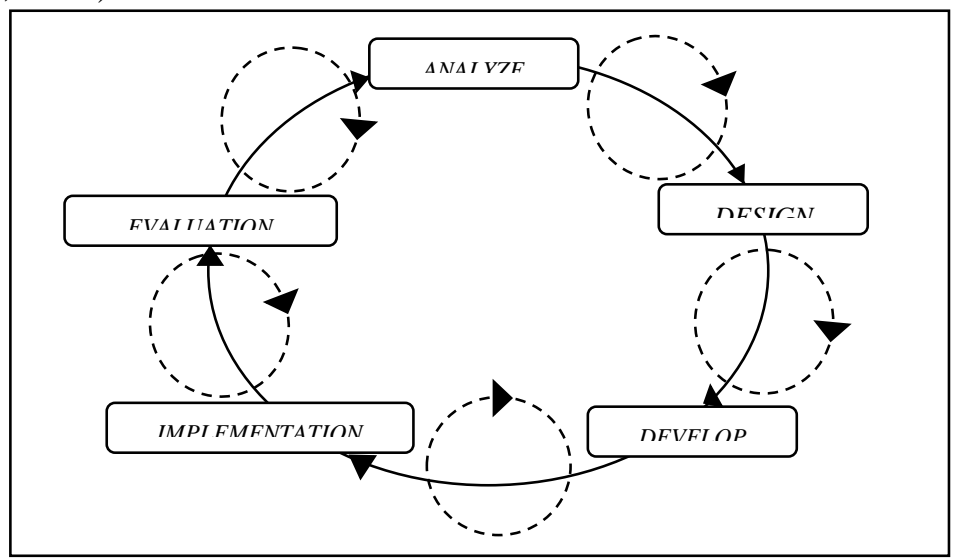

Gambar 1. Metode penelitian berdasarkan kerangka ADDIE

\section{HASIL}

Penelitian ini menghasilkan sebuah produk berupa media pembelajaran interaktif yang terintegrasi dengan soft skills untuk meningkatkan kemampuan pemecahan masalah siswa. Media pembelajaran 
interaktif yang dihasilkan berupa media interaktif powerpoint dengan materi pengolahan data untuk siswa kelas V di satuan pendidikan Sekolah Dasar (SD). Dalam media ini diintegrasikan soft skills siswa berupa motivasi. Motivasi yang diintegrasikan yaitu motivasi model ARCS, Attention (Perhatian), Relevance (Relevansi), Confidence (keyakinan/rasa percaya diri siswa), dan Satisfaction (Kepuasan). Penerapan ARCS ini dimaksudkan untuk memacu semangat siswa dalam kegiatan pembelajaran dan mampu meningkatkan kemampuan pemecahan masalah siswa. Integrasi keempat faktor tersebut dalam media pembelajaran yaitu:

1. Attention (perhatian) artinya peserta didik yang mau belajar harus memiliki perhatian pada materi yang akan dipelajari. Perhatian peserta didik dapat bangkit antara lain karena dorongan ingin tahu. Dalam integrasinya dalam media pembelajaran, desain media akan dibuat semenarik mungkin dengan penambahan gambar, video dan animasi yang menarik perhatian siswa.

2. Relevance (kesesuaian) artinya motivasi belajar akan tumbuh bila peserta didik merasakan bahwa apa yang dipelajari itu mempunyai kesesuaian manfaat langsung secara pribadi. Dalam integrasinya dalam media, dalam media akan diberikan contoh, latihan, atau tes yang langsung berhubungan dengan kondisi peserta didik.

3. Confidence (kepercayaan diri) artinya belajar secara aktif, perlu dihilangkan kekhawatiran dan rasa ketidakmampuan dalam diri peserta didik. Peserta didik perlu percaya bahwa ia mampu dan bisa berhasil dalam mempelajari sesuatu. Aspek confidence diintegrasikan di media pembelajaran interaktif ini diantaranya pada adanya menu pembahasan soal dan menu latihan soal kembali, dimana siswa dapat mencoba kembali soal yang telah dikerjakan.

4. Satisfaction (kepuasan) artinya bahwa motivasi belajar baru mampu menghasilkan rasa puas untuk mendorong tumbuhnya keinginan untuk tetap belajar. Dengan demikian, peserta didik akan termotivasi mencapai tujuan yang serupa. Demi meningkatkan dan memelihara motivasi peserta didik, guru dapat memberikan reinforcement (penguatan) berupa pujian, pemberian, kesempatan, atau bahkan pemberian hadiah. Aspek satisfaction diintegrasikan di media pembelajaran interaktif ini diantaranya pada adanya komentar interaktif ketika siswa menjawab soal dengan benar ataupun salah. Diakhir saat menyelesaikan semua soal siswa juga mendapatkan berupa kalimat ucapan penghargaan ketika telah mencapai target dan kalimat memotivasi pabila hasil belum sesuai target.

Hasil penelitian pengembangan media pembelajaran interaktif ini dijelaskan dalam beberapa tahapan desain pengembangan model ADDIE berikut ini.

\section{Tahap Analisis (Analysis)}

Tahapan ini merupakan tahapan awal dalam pengembangan media pembelajaran interaktif. Hasil analisis yang telah dilakukan dijadikan sebagai pedoman dalam pengembangan media pembelajaran interaktif. Analisis yang dilakukan diantaranya analisis kurikulum, analisis karakteristik siswa, analisis teknologi dan analisis pemanfaatan komputer sebagai media pembelajaran. 


\section{Tahap Perancangan (Design)}

Pada tahapan ini yang dilakukan adalah menyusun instrumen penilaian kualitas media pembelajaran, perancangan produk (storyboard), penyusunan materi, pengumpulan backsound, background, gambar dan tombol.

\section{Tahap Pengembangan (Development)}

\section{Membuat produk berupa media pembelajaran interaktif}

Pada tahapan ini media dibuat berdasarkan rencana pada storyboard yang telah dirancang sebelumnya. Media dibuat dari awal hingga akhir dengan menggunakan media powerpoint.

\section{Tampilan halaman pembuka}

Pada halaman pembuka ditampilkan judul dan materi media pembelajaran interaktif dengan ditampilkan beberapa animasi beberapa shapes dan font untuk masuk ke menu tampilan utama. Halaman ini merupakan halaman pertama yang tampil dalam media dan membawa masuk ke menu utama media pembelajaran interaktif.

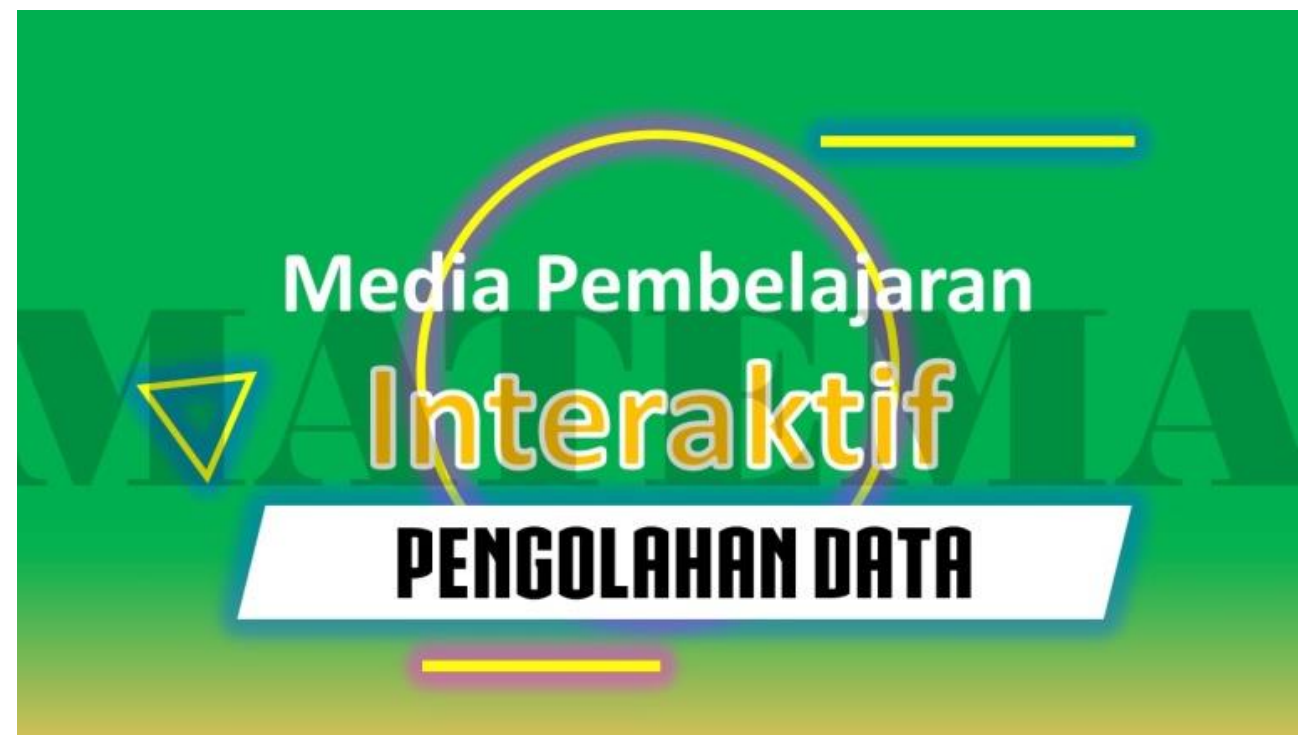

Gambar 2. Halaman Pembuka

Tampilan menu utama

Halaman menu utama terdapat menu-menu tombol navigasi yang sudah diberikan link untuk ke halaman yang telah ditentukan. Tombol-tombol navigasi diantaranya, tombol KD/IPK, tombol materi, tombol latihan dan tombol info. Selain tombol navigasi, pada menu utama diberikan animasi pada shapes, font dan gambar yang disisipkan dalam hamalan slide. 


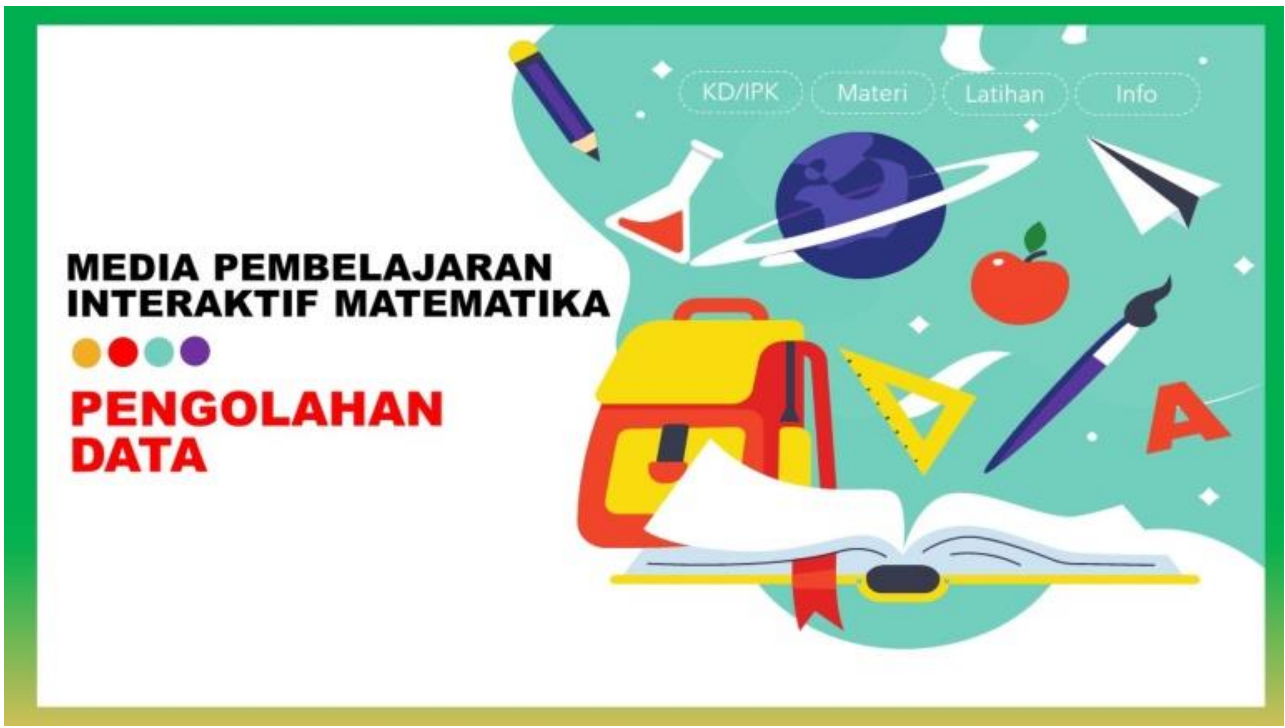

Gambar 3. Halaman menu utama

Tampilan pilihan menu KD/IPK

Pada pilihan menu KD/IPK ini telah dipaparkan tentang kompetensi dasar dan indikator pencapaian kompetensi yang dapat menjadi rujukan guru dalam pembuatan materi dan soal pada media pembelajaran interaktif yang akan dikembangkan.

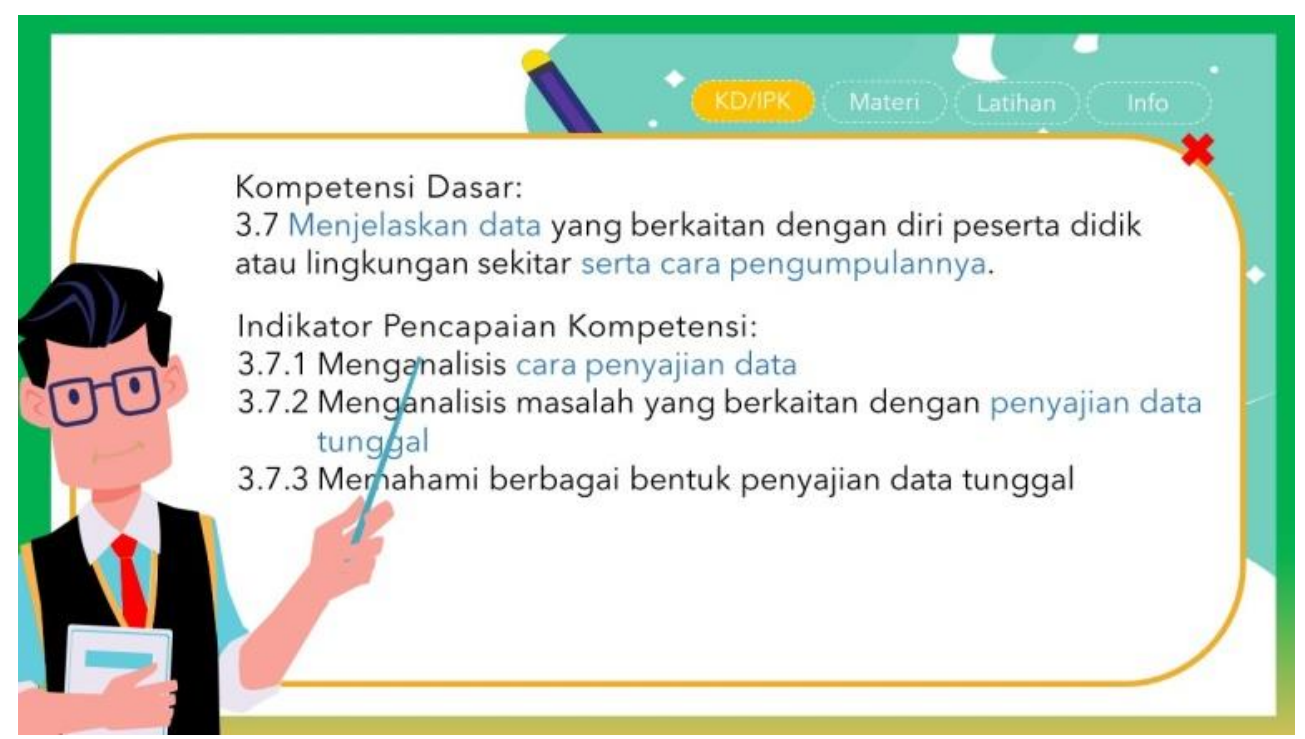

Gambar 4. Pilihan menu KD dan IPK

Tampilan Pilihan Menu Materi

Pilihan menu materi ditampilkan empat buah shape rectangle yang terdiri dari empat pembahasan materi, pendahuluan, mengumpulkan data, membaca data dan menyajikan data. Masingmasing tombol menu materi ini telah diberikan link untuk masuk ke halaman materi sesuai dengan tombol menu yang dipilih. 


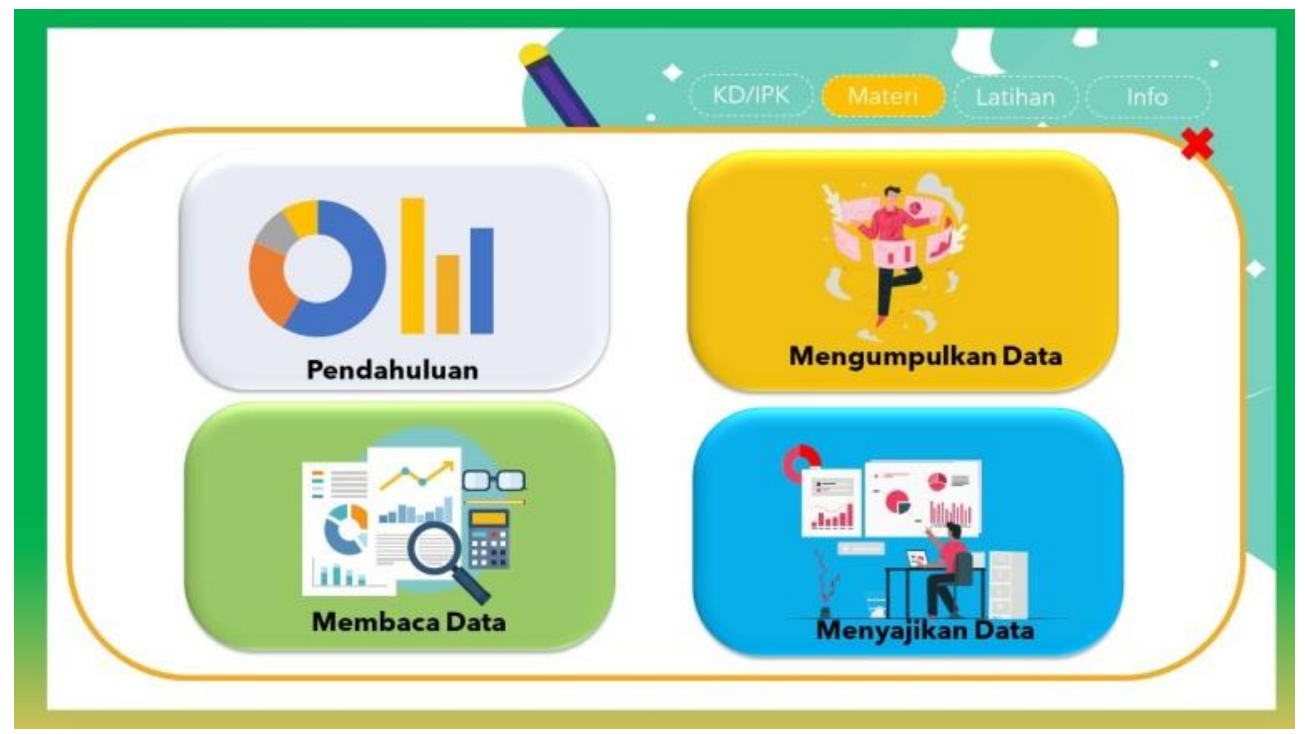

Gambar 5. Pilihan Menu Materi

Tampilan Pilihan Menu Latihan

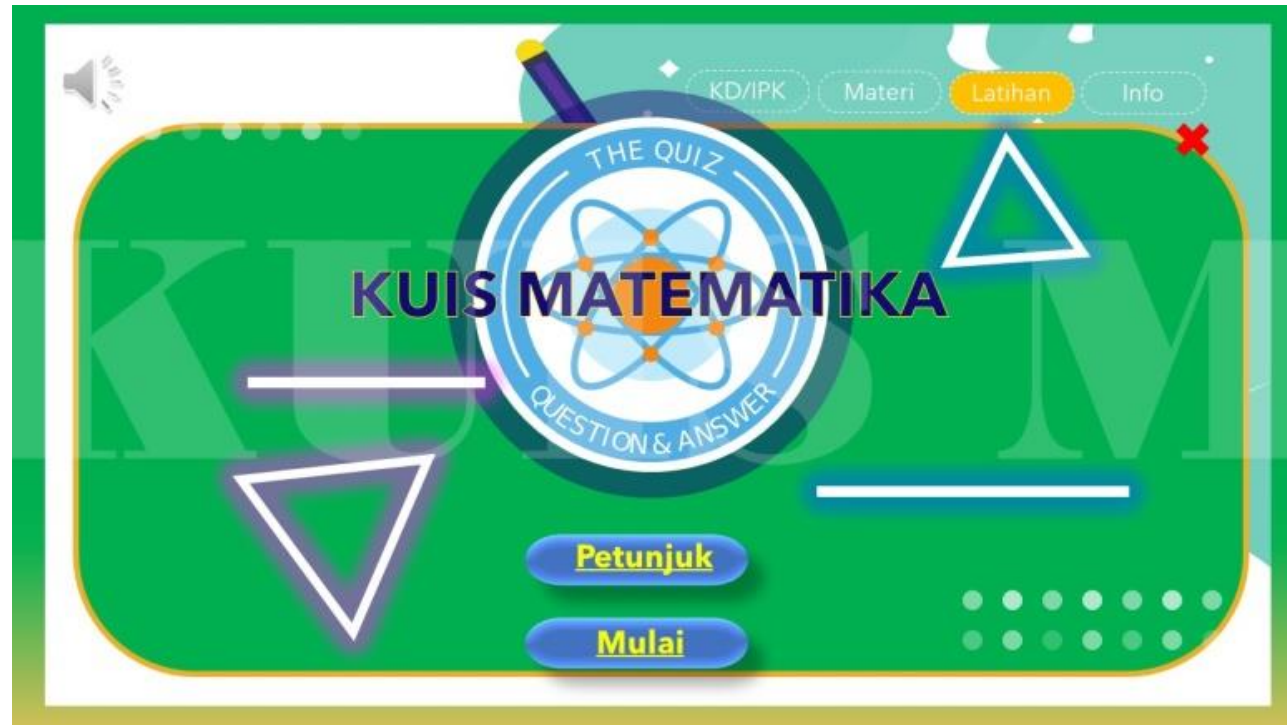

Gambar 6. Pilihan Menu Latihan

Tampilan pada menu latihan di media pembelajaran interaktif ini disisipkan tombol petunjuk dan mulai. Tombol petunjuk akan mengarahkan kepada halaman media yang menjelaskan petunjuk penggunaan untuk menu latihan, sedangkan tombol mulai untuk memulai latihan soal. Pada halaman ini diberikan musik pembuka dan diberikan animasi pada shapes dan font untuk membuat media terasa lebih menarik untuk digunakan oleh peserta didik.

Setiap halaman soal latihan ditambahkan musik yang membuat siswa merasakan sedang mengikuti kuis interaktif. Pada menu pilihan jawaban juga diberikan animasi yang menyatakan selamat jika menjawab benar, dan maaf jawaban belum benar untuk animasi jika memilih jawaban yang salah. Selain itu ditambahkan pula tombol home untuk kembali ke menu awal latihan, tombol silang untuk keluar menu. Tampilan soal sebagaimana nampak pada gambar 7. 


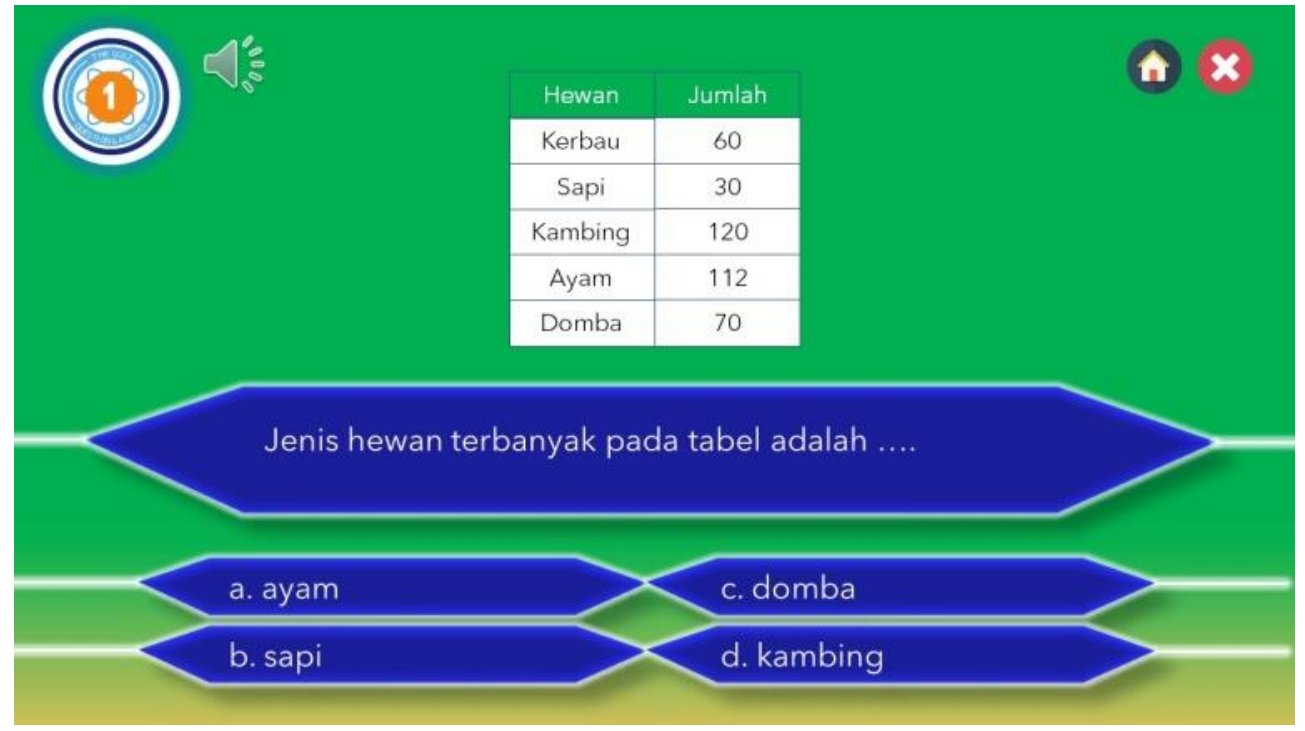

Gambar 7. Tampilan Soal

Saat selesai menjawab semua soal yang disajikan, maka tampil halaman yang menyajikan tiga tombol yaitu tombol lihat hasil untuk melihat nilai yang telah kita capai saat menjawab soal, tombol menu pembahasan untuk mengetahui bagaimana proses penyelesaian masalah soal yang telah disajikan, dan tombol latihan soal kembali untuk mencoba kembali soal yang telah disajikan. Nampak pada gambar 8 .

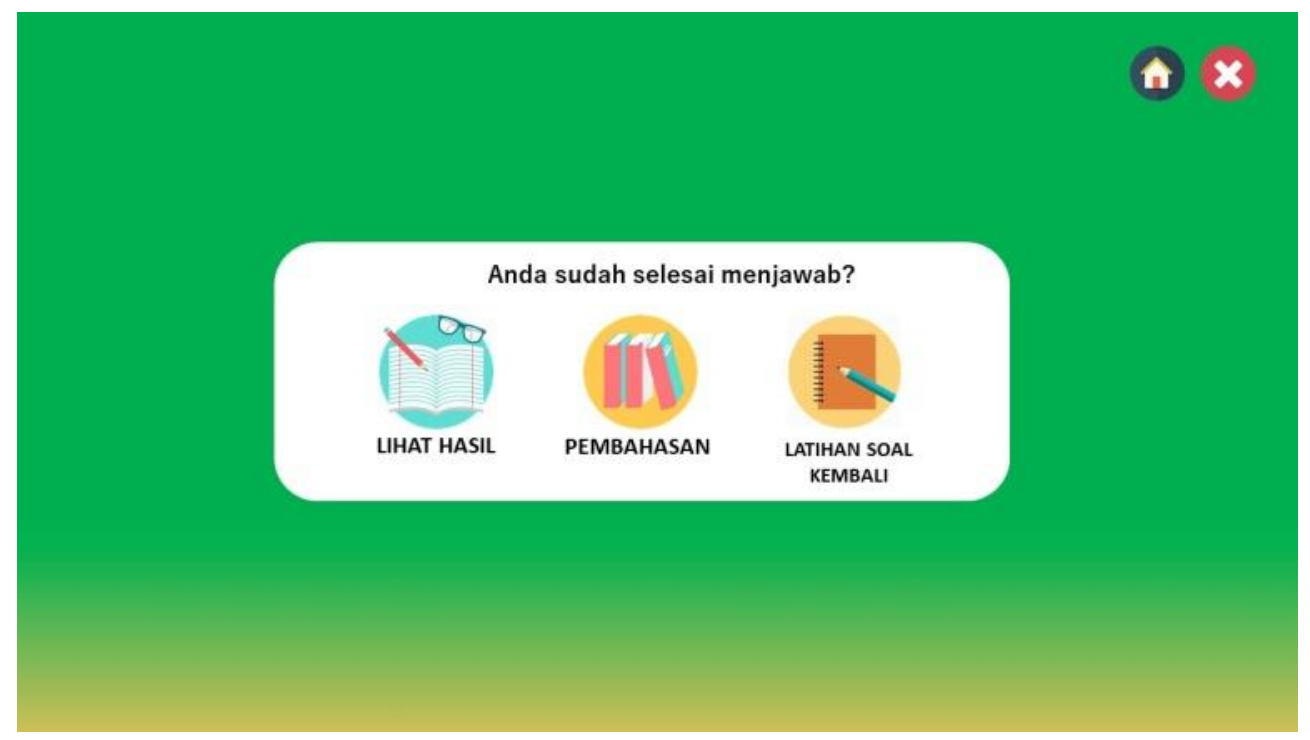

Gambar 8. Tampilan Menu Akhir

\section{Tampilan Menu Info}

Menu info merupakan menu yang menampilkan profil pembuat media pembelajaran interaktif powerpoint. Ditampilkan foto, nama, alamat website, alamat dan nomor kontak yang bisa dihubungi. 


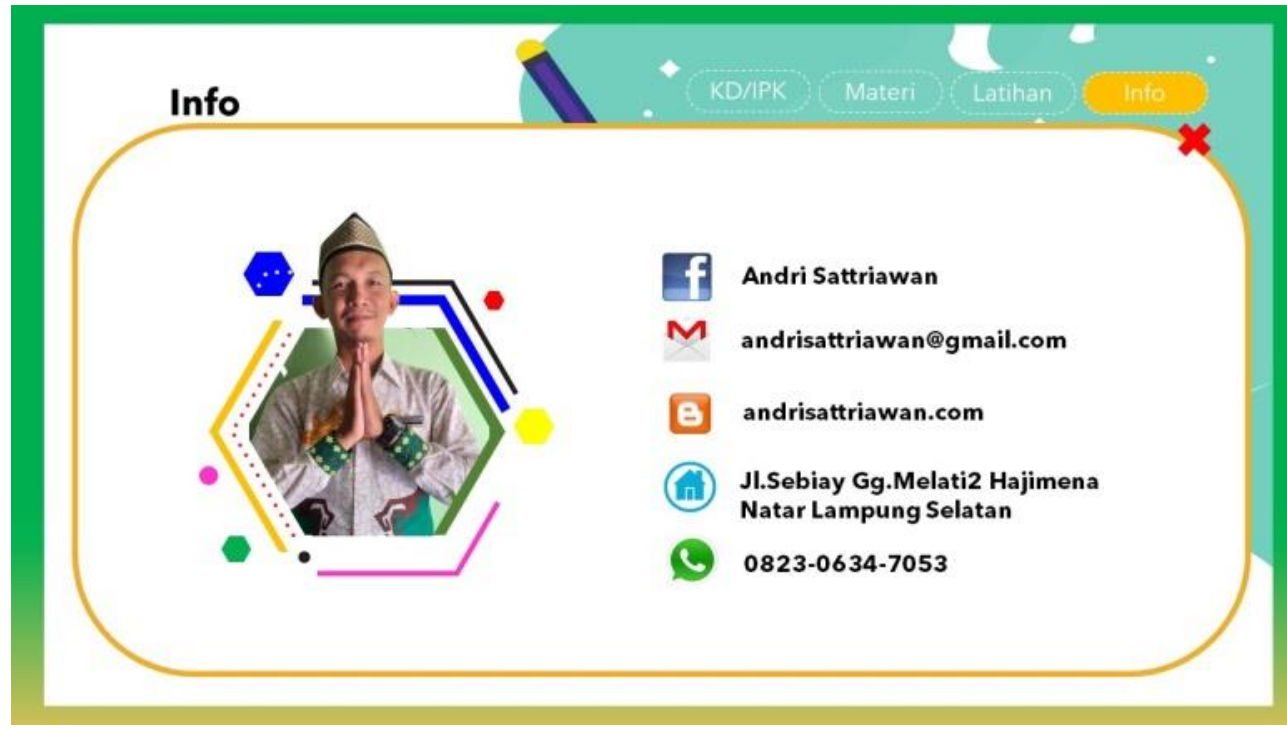

Gambar 9. Tampilan menu info

\section{Validasi Ahli Materi dan Ahli Media}

Proses validasi dilakukan oleh ahli media dan ahli materi. Hasilnya berupa saran, komentar dan masukan yang dapat digunakan sebagai dasar untuk melakukan analisis dan revisi terhadap media yang dikembangkan dan sebagai dasar untuk melakukan uji coba produk pada peserta didik.

\section{Revisi}

Penilaian ataupun evaluasi dari ahli materi dan media dijadikan acuan untuk memperbaiki media yang telah dibuat. Revisi dilakukan setelah review dari ahli yang disesuaikan dengan masukan, saran, dan kritik yang diberikan serta tetap disesuaikan dengan konsep pengembangan media pembelajaran interaktif tersebut.

\section{Hasil validasi ahli}

\section{Tabel 2}

Skor penilaian angket dari ahli materi

\begin{tabular}{|c|l|c|c|c|}
\hline \multirow{2}{*}{ No } & \multicolumn{1}{|c|}{ Aspek } & Validasi Ahli Materi & \multirow{2}{*}{ Rata-rata Skor } \\
\cline { 3 - 4 } & \multicolumn{1}{|c|}{ I } & II & \\
\hline 1 & Kualitas isi dan tujuan & $89 \%$ & $77 \%$ & $83 \%$ \\
\hline 2 & Kualitas instruksional & $94 \%$ & $76 \%$ & $85 \%$ \\
\hline 3 & $\begin{array}{l}\text { Kualitas pengintegrasian soft skills } \\
\text { terhadap media pembelajaran }\end{array}$ & $90 \%$ & $60 \%$ & $75 \%$ \\
\hline \multicolumn{2}{|c|}{ Rata-Rata Total Kriteria } & $91 \%$ & $71 \%$ & $81 \%$ \\
\hline \multicolumn{2}{|c|}{} \\
\hline
\end{tabular}

Berdasarkan data yang ditampilkan pada tabel 2, diketahui bahwa penilaian ahli materi terhadap media pembelajaran interaktif yang telah dikembangkan telah mencapai kriteria sangat valid dengan rata-rata total skor sebesar $81 \%$. Penilaian tersebut meliputi aspek kualitas isi dan tujuan, instruksional 
dan pengintegrasian soft skills terhadap media pembelajaran. Dilihat dari segi ketetapan konsep materi dalam media maka media pembelajaran ini dapat digunakan tanpa revisi.

\section{Tabel 3.}

Skor penilaian angket dari ahli media

\begin{tabular}{|c|l|c|c|c|}
\hline \multirow{2}{*}{ No } & \multicolumn{1}{|c|}{ Aspek } & Validasi Ahli Media & \multirow{2}{*}{$\begin{array}{c}\text { Rata-rata } \\
\text { Skor }\end{array}$} \\
\cline { 3 - 4 } & \multicolumn{1}{|c|}{ I } & II & $93 \%$ \\
\hline 1 & Kualitas Teknis & $97 \%$ & $88 \%$ & $75 \%$ \\
\hline \multicolumn{2}{|c|}{$\begin{array}{l}\text { Kualitas pengintegrasian soft skills terhadap } \\
\text { media pembelajaran }\end{array}$} & $90 \%$ & $60 \%$ & $84 \%$ \\
\hline \multicolumn{2}{|c|}{ Kata-Rata Total } & $94 \%$ & $74 \%$ & Sangat Valid \\
\hline
\end{tabular}

Berdasarkan data yang ditampilkan pada tabel 3, diketahui bahwa penilaian ahli media terhadap media pembelajaran interaktif yang telah dikembangkan telah mencapai kriteria sangat valid dengan rata-rata skor sebesar $84 \%$. Sebagaimana tabel kriteria kelayakan media pada tabel 4 .

\section{Tabel 4}

Kriteria penilaian data persentase validitas produk

\begin{tabular}{|c|l|}
\hline Kriteria Validitas & \multicolumn{1}{c|}{ Tingkat Validitas } \\
\hline $85,01 \%-100,00 \%$ & Sangat valid, atau dapat digunakan tanpa revisi \\
\hline $70,01 \%-85,00 \%$ & Cukup valid, atau dapat digunakan namun perlu direvisi kecil \\
\hline $50,01 \%-70,00 \%$ & Kurang valid, atau tidak digunakan karena perlu revisi besar \\
\hline $01,00 \%-50,00 \%$ & Tidak valid, atau tidak boleh dipergunakan \\
\hline
\end{tabular}

Penilaian tersebut meliputi aspek kualitas teknis dan pengintegrasian soft skills terhadap media pembelajaran. Dilihat dari segi ketetapan konsep materi dalam media maka media pembelajaran ini layak untuk diujicobakan.

\section{Tahap Implementasi (Implementation)}

Media pembelajaran interaktif yang telah dikembangkan serta telah dinyatakan valid dan layak uji, selanjutnya diujicobakan kepada guru dan siswa. Guru matematika dua orang dan siswa sebanyak 5 siswa. Hasil uji coba tersebut da[at dilihat sebagai berikut.

\section{Hasil analisis respon guru terhadap media pembelajaran}

\section{Tabel 5}

Persentase respon guru terhadap media pembelajaran

\begin{tabular}{|c|c|c|c|c|}
\hline \multirow{2}{*}{ No } & \multirow{2}{*}{ Aspek } & \multicolumn{2}{|c|}{ Uji Praktisi } & \multirow[t]{2}{*}{ Rata-Rata Skor } \\
\hline & & $\mathrm{I}$ & II & \\
\hline 1 & Kualitas isi dan tujuan & $91 \%$ & $87 \%$ & $89 \%$ \\
\hline 2 & Kualitas instruksional & $86 \%$ & $78 \%$ & $82 \%$ \\
\hline 3 & Kualitas teknis & $84 \%$ & $84 \%$ & 84 \\
\hline
\end{tabular}


Pengembangan Media Pembelajaran Interaktif Terintegrasi Soft Skills Dalam Meningkatkan Kemampuan Pemecahan Masalah, Andri Sattriawan, Sugeng Sutiarso, Undang Rosidin

\begin{tabular}{|c|l|c|c|c|}
\hline 4 & $\begin{array}{l}\text { Kualitas pengintegrasian soft skills terhadap media } \\
\text { pembelajaran }\end{array}$ & $93 \%$ & $85 \%$ & $89 \%$ \\
\hline \multicolumn{2}{|c|}{ Rata-rata skor } & $89 \%$ & $84 \%$ & $86 \%$ \\
\hline Kriteria & Sangat Praktis \\
\hline
\end{tabular}

Berdasarkan tabel 5, persentase respon guru terhadap media pembelajaran interaktif mencapai persentase rata-rata total sebesar $86 \%$ yang termasuk dalam kriteria sangat praktis. Sebagaimana penjelasan pada tabel 7. Sehingga dengan hasil ini maka media pembelajaran interaktif yang telah dikembangkan layak untuk digunakan.

\section{Tabel 6}

Kriteria penilaian data persentase kepraktisan produk

\begin{tabular}{|c|c|}
\hline Persentase & Kriteria \\
\hline $81 \%-100 \%$ & Sangat Praktis \\
\hline $61 \%-80 \%$ & Praktis \\
\hline $41 \%-60 \%$ & Cukup Praktis \\
\hline $21 \%-40 \%$ & Kurang Praktis \\
\hline $0 \%-20 \%$ & Tidak Praktis \\
\hline
\end{tabular}

\section{Hasil analisis respon siswa terhadap media pembelajaran}

\section{Tabel 7}

Persentase respon siswa terhadap media pembelajaran

\begin{tabular}{|c|l|l|c|}
\hline No & \multicolumn{1}{|c|}{ Aspek } & \multicolumn{1}{|c|}{ Idikator } & Skor \\
\hline 1 & Attention (Perhatian) & $\begin{array}{l}\text { Menangkap kepentingan siswa dan merangsang } \\
\text { rasa ingin tahu siswa untuk belajar }\end{array}$ & $89 \%$ \\
\hline 2 & Relevance (Relevansi) & $\begin{array}{l}\text { Memenuhi kebutuhan pribadi/tujuan pelajar } \\
\text { untuk efek sikap positif }\end{array}$ & $86 \%$ \\
\hline 3 & Confidence (Percaya Diri) & $\begin{array}{l}\text { Membantu siswa memiliki rasa percaya } \\
\text { diri/merasa bahwa siswa dapat berhasil dan } \\
\text { mengontrol keberhasilan siswa }\end{array}$ & $83 \%$ \\
\hline 4 & Satisfaction (Kepuasan) & $\begin{array}{l}\text { Memperkuat prestasi dengan reward (internal } \\
\text { dan luar) }\end{array}$ & $92 \%$ \\
\hline \multicolumn{2}{|l|}{ Rata-Rata Total } & Sangat Praktis \\
\hline
\end{tabular}

Berdasarkan tabel 6 , persentase respon siswa terhadap media pembelajaran interaktif mencapai rata-rata total sebesar $88 \%$ yang termasuk dalam kategori sangat praktis. Sehingga dengan hasil ini maka media pembelajaran interaktif yang telah dikembangkan layak untuk digunakan. 
Tahap Evaluasi (Evaluation)

Hasil uji coba produk yang dilakukan oleh guru matematika dan siswa berdasarkan pada Tabel 5 dan 7 menunjukkan bahwa guru dan siswa memberikan respon positif teradap media pembelajaran yang telah dikembangkan dengan kriteria sangat praktis. Dalam pengembangannya berbagai masukan dan saran baik dari guru maupun siswa menjadi bahan evaluasi untuk perbaikan media yang dikembangkan.

\section{KESIMPULAN}

Berdasarkan hasil penelitian dan pembahasan pada Bab IV diperoleh simpulan sebagai berikut: 1) Hasil validasi ahli materi terhadap media pembelajaran interaktif terintegrasi soft skills yang telah dikembangkan telah mencapai kategori sangat valid dengan rata-rata total skor sebesar $81 \%$. Sehingga media ini layak untuk digunakan. 2) Hasil validasi ahli media terhadap media pembelajaran interaktif terintegrasi soft skills yang telah dikembangkan telah mencapai kategori sangat valid dengan rata-rata total skor sebesar 84\%. Sehingga media ini layak untuk digunakan. 3) Hasil uji coba praktisi menunjukan kepraktisan media dengan kriteria sangat praktis dengan rata-rata total skor sebesar $86 \%$. 4) Hasil uji coba siswa menunjukan kepraktisan media dengan kategori sangat praktis dengan rata-rata total skor sebesar 88\%. 5) Media pembelajaran interaktif terintegrasi soft skills yang telah dikembangkan layak untuk digunakan sebagai media pembelajaran.

Berdasarkan hasil kesimpulan dan penelitian, dikemukakan saran-saran sebagai berikut: 1) Media pembelajaran interaktif terintegrasi soft skills ini dapat digunakan sebagai media pembelajaran siswa kelas V sekolah dasar pada materi pengolahan data. 2) Pembaca dan peneliti lain dapat mengembangkan media ini dengan mengintegrasikan soft skills lainnya baik pada materi pengolahan data maupun materi lainnya. 3) Pembaca dan peneliti lainnya dapat menguji efektivitas media yang telah dikembangkan ini dengan kemampuan yang harus dimiliki siswa.

\section{DAFTAR PUSTAKA}

Alex, K. (2014). Soft Skill Know Yourself And Know The Word. Rajendra Ravindra.

Căprioară, D. (2015). Problem Solving - Purpose and Means of Learning Mathematics in School. Procedia - Social and Behavioral Sciences. https://doi.org/10.1016/j.sbspro.2015.04.332

Chamorro-Premuzic, T., Arteche, A., Bremner, A. J., Greven, C., \& Furnham, A. (2010). Soft skills in higher education: Importance and improvement ratings as a function of individual differences and academic performance. Educational Psychology. https://doi.org/10.1080/01443410903560278

Hendriana, H., Rohaeti, E.E., \& Sumarmo, U. (2017). Hard Skills dan Soft Skills Matematika Siswa. Refika Aditama. 
Hidayati, W.S., \& A. (2015). Integrasi Soft Skills dalam Pembelajaran. Prosiding Seminar Nasional Hasil Penelitian Pendidikan Dan Pembelajaran STKIP PGRI Jombang, 1(1), 51-56.

NCTM. (2000). Principles and Standards for School Mathematics Overview. Journal of Equine Veterinary Science.

Nursit, I. (2016). Pengembangan multimedia interaktif berbasis power point (macro-enabled) pada mata kuliah geometri euclid dalam pembelajaran matematika. Media Pendidikan Matematika.

Rohendi, D. (2012). Developing E-Learning Based on Animation Content for Improving Mathematical Connection Abilities in High School Students. IJCSI International Journal of Computer Science Issues, 9.

Rusdi, M. (2018). Penelitian Desain dan Pengembangan Kependidikan. In Depok: PT. RajaGrafindo Persada.

Suminta. (2016). Ektivitas Model Pembelajaran Open Ended Dengan Media Power Poin Pada Materi Lingkaran Dan Bangun Ruang Kubus Dan Balok. Jurnal E-DuMath, 2(1), 28-37.

Suprapti, E. (2016). Pengembangan Perangkat Pembelajaran Matematika Model Kooperatif Tipe STAD dengan Media Powerpoint Ispring pada Materi Jajargenjang, Layang-Layang dan Trapesium di Kelas VII SMP. MUST: Journal of Mathematics Education, Science and Technology. https://doi.org/10.30651/must.v1i1.98 